\title{
Due To Legal Determination Of Religious Courts Demak Decision No. 09 / PDT.P / 2018 / PA DMK About Adoption Realization
}

\author{
Rodiyah $^{1}$ and Akhmad Khisni ${ }^{2}$
}

Abstract. Society has long recognized the legal institution of adoption even before the time of the Prophet society has implemented a system of adoption with the motivation or a different purpose, among others, to continue the descent, carry on business and so on. In Indonesian society not many people know about the implementation process since the adoption in court litigation adoption petition, the case investigation in the trial until the stage of determination of the judge.

This study uses the approach of law (statute aproach) and approach to the case. Law approach is used to determine the overall legal regulations, especially laws governing adoption in Indonesia. Case approach aims to study the application of norms or rules of law in the determination of adoption.

The results of this thesis research in the Stipulation No. 09 / Pdt.P / 2018 / PA.Dmk is the implementation of adoptions carried out aimed at the best interests of children in the welfare and protection of children and the application of law by the judge in legal considerations. As a result of the law of the designation is the association adopted child with the adoptive parents only form of legal relationship in the form of transfer of responsibility of the biological parents and not result in legal consequences inherit each other between himself and his adoptive parents are not entitled to inherit each other to each other, but the adopted child can accept the will, and vice versa.

Keywords: Because of Law; Kids Appointment; Religious Courts.

\section{Introduction}

Child is deposited and also the grace of God the almighty, even the child is a treasure more valuable than other properties. Therefore, we must always maintain and protect the child in the child because there is dignity, and rights as human as us adults in general. Child, for the full development of his personality and harmony should be growth and development in an environment of a happy family, loving and understanding. ${ }^{3}$

In article 28 of the $4^{\text {th }}$ Amendment to the Constitution of 1945, on Human Rights, ${ }^{4}$ that every child has the right, namely the right to life, survival and development. The principle to life, survival and development is the most fundamental rights for children who are protected by the State, Government, Society, family and parents. As stated in Article 52 paragraph (1) and (2) of Act No. 39 Of 1999 on Human Rights, on the article 52 paragraph (1) and (2) as follows:

\footnotetext{
${ }^{1}$ Student of Master of Law, Universitas Islam Sultan Agung Semarang and Deputy Chaiman of Religious Court Kotabumi, email rodiyah.sjj@gmail.com

${ }^{2}$ Faculty of Law Universitas Islam Sultan Agung

${ }^{3}$ Koesparmono Irsan, 2009, Hukum dan Hak Asasi Manusia, Yayasan Brata Bhakti, Jakarta, p 63.

${ }^{4} 4^{\text {th }}$ Amendment Act of 1945
} 
(1) Every child is entitled to protection by parents, families, communities and countries.

(2) Child rights are human rights and for the benefit of the child's rights are recognized and protected by law even in the womb. ${ }^{5}$

As stated in Article 4 paragraph (1) of Act No. 4 of 1979 About Welfare of the Child that the child has no parents are entitled to care by the state or any person or entity. ${ }^{6}$

Communities are very involved in child protection, the public are entitled to the widest possible opportunity to participate in the protection of children and implement them in accordance with the provisions of the legislation in force. ${ }^{7}$

Adoptions aimed at the best interests of the child in order to realize the child welfare and protection of children, which are implemented based on local custom and the provisions of the legislation. ${ }^{8}$ Ordinary people have not much is known about how the process of adoptions carried out in the Religious as well as the conditions that must be met by the prospective adoptive parents and the biological parents prospective adopted children, as well as the legal consequences for adopted children, adoptive parents and the biological parents after the court decision on the adoption of children who have been legally binding.

In this case the Islamic Court as an institution is authorized to receive, check and set the case of adoption petition against Indonesian citizens who are Muslims would provide the best legal services to the public especially those who want to apply for adoption. With regard to the request for adoption of the panel of judges will consider whether or not the application is granted in accordance with the evidence available under the legislation in force. There are indicators that can be used to see and feel that a decision or determination has fulfilled a sense of justice or not. Among other indicators can be found in the legal reasoning used judges. Legal considerations are fundamental arguments the judge in deciding a case. So accurate to say that the success of a judge can be seen from the judgment because the Decision is the crown of a judge. With the court ruling granting adoption request would have caused as a result of a new law for the adoptive parents and the adopted child and the biological parents of the adopted child.

Based on the above authors are interested to discuss about the, "Due To Legal Determination Of Religious Courts Demak Decision no. 09 / Pdt.P / 2018 / PA Dmk About Adoption Realization". this study tried to answer the problem of the implementation process of the establishment of the adoption by the Religious Court Demak, analytical consideration of the judge in the case and grant the legal consequences of the granting of a case No.09 / Pdt.P / 2018 / PA Dmk on the adoption of the child.

\footnotetext{
${ }^{5}$ Indonesia, the Law on Human Rights, No. 39 of 1999, LN, 1999 No. 165, Supplement No. 3886, Article 52.

${ }^{6}$ Indonesia, Act On Child Welfare, No. 4 of 1979, Gazette of 1979 Number 32, Supplement No. 3143, Article 4.

${ }^{7}$ Apong Herlina, et. Al., 2003, Perlindungan Anak, based on Act No. 23 of 2002 on Child Protection, Jakarta, UNICEF, p. 37.

${ }^{8}$ Government Regulation on the Implementation of Child Adoption, Government Regulation No. 54 of 2007, Gazette of 2007 Number 123, Supplement No. 4768, Article 2.
} 
This study will be prepared using the type of normative juridical research, the research focused on reviewing the application of the rules or norms of positive law. ${ }^{9}$ Normative juridical approach that uses legis positivist conception. ${ }^{10}$ This study uses the approach of law (statute aproach) and approach to the case. Specifications of research used is descriptive analytical research that explained, describe or disclose data that have relevance to the above problems. ${ }^{11}$ Data collection techniques with documentation data obtained from the determination of child adoption case in Demak Religious Court No. 09 / Pdt.P / 2018 / PA.Dmk as primary data and through interviews with the judges. Because this study is literature, interview technique was used as a support in data collection, so that the data obtained is a secondary data. The analytical method used is the analysis of qualitative data.

\section{Results And Discussion}

\subsection{Adoption Process of Determination Decision No. 09 / Pdt.P / 2018 / PA Dmk.}

The implementation of the adoptions in Religious Court Demak the following details ${ }^{12}$ :

- Stage application for adoption; This stage should be done by a person who will carry out adoptions in Religious Court Demak, the adoption petition addressed to the Chairman of the Religious which prospective foster child lived. In applying for a child adoption can be submitted in person or by a proxy.

- Stage Examination on Trial; The second stage in the adoption proceedings is the stage of court examination, which is a process of adoption petition shall be examined by the judges. At this stage the application submitted by the applicant is tested truth by the judge. Thus at this stage is a testing phase to the demands of the applicant.

Evidence in the case of adoption petition in Religious Court Demak is proving to letters and witnesses. The meaning of written evidence or a letter everything that contains signs reading intended to convey one's thoughts for the purpose of verification. As presented by Dra. Ulfah as the judge determined that to strengthen the arguments of the petition of adoption applicants are asked to submit the paperwork that will be used as evidence, in the form of photocopies excerpts marriage certificate, the original family consensus to adopt a child, copy of birth certificate, SKCK of police ID card applicant, and the certificate of Income, further explained that the paperwork that must be sufficiently stamped and dinazegelen.

From the research results Decision No. 09 / Pdt.P / 2018 / PA Dmk, at this stage of the examination hearing witnesses to testify as follows:

- The first witness Muhammad Djayadi $\mathrm{H}$ bin Adnan, is the biological father-in-law of Petitioner I and Petitioner II, knowing the Petitioners are husband and wife were married in 1999, but until now they have not been blessed with children.

\footnotetext{
9Johnny Ibrahim, 2006, Teori dan Metodologi Penelitian Hukum Normatif, Malang, Bayumedia Publishing, p. 295.

${ }^{10}$ Ronny Hanitijo Soemitro, 1988, Metodologi Penelitian Hukum dan Jurimetri, Jakarta, Ghalia Indonesia,p. 13-14.

11 Ibid, p 26-27.

${ }^{12}$ Interview with Dra. Ulfah, Religious Court Demak
} 
The Applicant intends to apply for adoption named Muhammad Zavin Elfarezi (age 17 months), the child's parents named Abdul Ghammam and Mastianah, who is the younger brother of Petitioner I, the prospective adopted child aged 1 year and 5 months, and has been cared for and nurtured by the applicant since birth, parents / fathers and mothers of these children do not mind if his son was adopted by the applicant because the applicant belong to someone who is able and affluent, good morals, religious, responsible, affectionate to children and have never been involved in acts of criminal.

- Heni Yustianingsih is a neighbor of the Petitioners since childhood, familiar with the Petitioners, the witness knew himself both husband and wife are legitimate, married in 1999, and has not been blessed with children, they intend to apply for adoption named Muhammad Zavin Elfarezi (age 17 months), while the child's parents named Abdul Ghammam bin Sutrisno and Mastianah bint Djayadi, until now still alive, the prospective adopted child aged 1 year and 5 months, has joined the Petitioners, in a state of well-maintained and healthy, Petitioner I is the older brother of Mastinah bint Djayadi (mother of the child), the Applicant worked as a merchant of poultry with monthly income of Rp 30.000.000,00 (thirty million rupiahs), so that belong to someone who is able and affluent,as well as good morals, religious, responsible, affectionate to children and have never been involved in criminal acts, as long as the child is in the care of the applicant no one objected.

- Phase Judge Decision

The meaning of the decision / determination of the judge is a statement by the judge as a state official who was authorized to be spoken in the trial and it aims to end or settle a problem. The judge used as the basis in determining the application for child adoption case based on interviews with Dra. Ulfah as the judge said that the consideration of the judge in determining the petition of adoption cases can be divided into two, namely: consideration of the principal case and consideration of the law. Further explained that consideration of the principal case contains considerations about the chronology of adoption and the things that happened in the trial, such as a description of the applicant, birth parents and prospective adoptive child proof. While consideration of the law contains a consideration of the purpose and the reason of the applicant's conduct adoption, and domestic economic circumstances of the applicant, the applicant way to educate and foster parenting, character of the applicant, the image of the child's future after the foster child made by the applicant. At the hearing the judge set a substitute registrar grant aided adoption cases filed by the Applicant.

\subsection{Analysis of consideration of Decision No. 09 / Pdt.P / 2018 / PA Dmk. on the Application for Adoption}

Adoption Request No. 09 / Pdt.P / 2018 / PA.Dmk have met the formal requirements to be accepted and examined by a panel of judges based on the following matters:

- Case Adoption became its jurisdiction because it was included in the marriage implemented under Islamic law, it is based on the elucidation of Article 49 (a) of Act No. 3 of 2006 regarding the amendment of Act No. 7 of 1989 on the Religious and 
based explanations No. 37 of article 49 (a) No.s (20) jo. Article 171 letter (h) Compilation of Islamic Law.

- The petitioners and the prospective adopted children residing in the jurisdiction of the Religious Court Demak, based on Article 118 HIR and Supreme Court Decision No. KMA / 032 / SK / IV / 2006 on the enforcement of Book II of the Code of Duties and Administrative Court, the case is relative authority Religious Court Demak;

- The Applicant intends to raise up a boy named Muhammad Zavin Elfarezi born in Demak on August 1, 2016 of married couples Abdul Ghamam and Mastianah, solely in the interest and welfare of the child, hence the Petitioners have legal standing to apply for adoption ,

The demands of the applicant is essentially begging Religious Court Demak assign the applicant as a foster parent legitimate from a boy named Muhammad Zavin Elfarezi bin Abdul Ghammam who was born on August 1, 2016, the residence in Demak, where appointment the children have been eligible under the applicable law.

Based on the written evidence in the form of a photocopy of the ID card in the name of the applicant, Citation Certificate, Copy of Police Notes, on behalf of the applicant, Copy of Statement of Consent Families for Raising Children, certificates of income applicant, Copy of Identity Card, parents bladder prospective foster child, Copy Excerpt of Birth Certificate, Muhammad Zavin Alfarezi, child Submission Copy, Copy of Decree of the Head of Social Service of Central Java province on Issuance of Permit to prospective foster Parents Subagiono And Fatmawati to do Appointment candidates adopted Muhammad Zavin AlFarezi.

All the evidence is already sufficiently stamped and stamped posts and by the panel of judges has been matched and was in accordance with the original, has qualified the formal and material as evidence so that it can be accepted as evidence and can be considered.

Legal Basis realization adoption petition by the applicant is:

- Qur'an Surah Al-Ahzab paragraphs 4 and 5.

- MUI Fatwa No. 4335 / MUI / 82 dated June 18, 1982, to coincide with the $18^{\text {th }}$ of Sha'ban $1402 \mathrm{AH}$.

- Article 39 paragraph (3) of Act No. 23 of 2002 on Protection of Children, as amended by Act No. 35 of 2014.

- Article 2, Article 3, paragraph (1) and (2), Article 4 and Article 6 paragraph (1) and (2) the Indonesian Government Regulation No. 54 of 2007 on the Implementation of Adoption.

- Supreme Court Circular No. 2 of 1979.

- Supreme Court Circular No. 6 of 1983

- Supreme Court Circular No. 3 of 2005

- Article 171 letter (h) Compilation of Islamic Law (KHI)

- Social Ministerial Decree No. 41 / HUK / KEP / VII / 1984.

2.3 Effects of Determination Decision No. 09 / Pdt.P / 2018 / PA Dmk. About Adoption Realization 
Adoptions under Islamic law adoption is rooted in the Quran and the Sunnah and the results of ijtihad prevailing in Indonesia formulated in various products of Islamic legal thought, either in the form of fiqh, fatwa, court decisions or legislation. ${ }^{13}$ There dignifikan difference in terms of the legal consequences of adoption, the Law of the West (BW) with Islamic law. In western law (BW) adopted child to inherit as a child, not as a stranger. ${ }^{14}$ In Islamic law adopted children are not necessarily entitled to the inheritance. The entry of adopted children in family foster parents can lead to hostility between the descendants of the family. Foster children should not inherit but be heirs, thus closing the section that should be distributed to the heirs who deserve it.

In accordance with the legal system of fostering diversity in the various regions in Indonesia, the views of the community in relation to the position of angkatpun diverse children anyway. Some adopted children inherit from the adoptive parents in the form of original property and community property, but sometimes only the joint property only. ${ }^{15}$ While adoptions under Islamic law essentially allowed but solely based on the objective to help the abandoned children and it does not carry any legal consequences. This is because under Islamic law there are restrictions in terms of adoption adoption to the child that is giving equal status to the status of biological children.

Adoption according to Islamic law will not result in a blood relation rights, guardianship and inheritance with his biological parents. Adopted children still wear the name of his biological parents, and continues to be the heir of his biological parents. ${ }^{16}$

Thus the principle of adoption under Islamic law in accordance with Islamic Shari'ah law will result in the following:

- Adoption Not Result in Changes nasab; In terminological nasab is heredity or family ties as blood ties, either by birth upwards (father, grandfather, mother, grandmother, and so on), down (children, grandchildren, and so on) or laterally (brothers, uncles, and other -other). ${ }^{17}$

- Causes No Child appointment of Mutual Inherited Effects

In the case of inheritance, according to the jurists there are three factors that cause a person to inherit each other, namely because of kinship or descent (al-qarabah) as a result of legal marriage (al-mushaharah), and because of the relationship trust between slave and guardian who gave him his freedom or because of factors helping each other between a person and the person who inherited during his lifetime. While the adopted child is not included in the three categories above, in the sense that not a relative or one offspring with foster parents, nor born of legitimate marriage of foster parents, and not because the trust relationship. Therefore, between him and his adoptive parents are not entitled to inherit from each other mutually,

\footnotetext{
${ }^{13}$ Mukti Arto, 2006, Garis Batas Kekuasaan Pengadilan Agama dan Pengadilan Negeri, in Varia Peradilan year XXI No. 52, MA RI, Jakarta, p. 14.

${ }^{14}$ B. Ter Haar, 1985, Asas-Asas dan Susunan Hukum Adat, translated by K. ng Soebakti Poesponot, Jakarta Pradnya Paramita, p. 247.

15 Isti Sulistyorini, 1997, Adopsi Menurut Staatsblad 1917 No. 129 Dan Kaitannya Dengan Pengangkatan Anak Menurut Hukum Adat, PENA, Jurnal Ilmu pengetahuan Dan Teknologi: V (9), p. 27.

${ }^{16}$ M. Budiarto, 1991, Pengangkatan Anak Ditinjau Dari Segi Hukum, Jakarta, Akademika Presindo, p. 2.

${ }^{17}$ Ensiklopedi Indonesia, 1994, Jakarta, Ichtiar Baru Van Hoeve, $1^{\text {st }}$ Edition, Chapter 4, p. 2337.
} 


\section{Closing}

\subsection{Conclution}

The conclusion of this thesis is as follows:

- The implementation process Determination Decision of No. 09 / Pdt.P / 2018 / PA Dmk. on the application for adoption, in accordance with the procedures applicable procedural law and in accordance with the Guidelines for the Implementation and Administration of Justice Task Religion, since the litigation stage of adoption petition, the case investigation at the trial stage and the stage of the Decision / Determination of Justice.

- Legal Basis realization adoption petition by the applicant is the Qur'an Surah AlAhzab verse 4 and 5, the MUI Fatwa No. 4335 / MUI / 82 dated June 18, 1982, Article 39 paragraph (3) of Act No. 23 Of 2002 regarding Child protection as amended by Act No. 35 of 2014, Article 2, Article 3, paragraph (1) and (2), Article 4 and Article 6 paragraph (1) and (2) the Indonesian Government Regulation No. 54 Of 2007 on Implementation adoption, the Supreme Court Circular No. 2 of 1979, the Supreme Court Circular No. 6 of 1983, the Supreme Court Circular No. 3 of 2005, Article 171 letter (h) Compilation of Islamic Law (KHI), and the Social Minister No. 41 / HUK / KEP / VII / 1984.

- Legal consequences arising from the determination of the appointment of the child is the child's relationship adoptive parents of origin is still there (no change nasab), the association adopted child with the adoptive parents only form of legal relationship in the form of transfer of responsibility from the parents of origin and does not lead to a result inherit each other law between himself and his adoptive parents are not entitled to inherit from each other mutually, but an adopted child can receive a testament later in the compilation of Islamic law stipulates that the adopted child with the adoptive parents or the opposite happens relationship was borrowed.

\subsection{Suggestion}

- Need to socialize their child protection laws in order to prevent the abandonment of children and to protect the future of children by promoting the movement of foster parents.

- Many people who are interested in the institution of adoption, but still lacking the information that is necessary to socialize / legal counseling for prospective adoptive parents about the effects of adoption includes the rights and responsibilities of parents and the adopted child under the applicable law / positive there.

- Need to ratification adoptions are conducted outside the court that has been carried out for many years even after the child has grown, the implementation of the removal of the child can be adopted through the courts, in order to achieve fairness, certainty, the benefit of the law and the legal protection of the adopted child and the adoptive parents, 


\section{Bibliography}

[1] Apong Herlina, et. Al., 2003, Perlindungan Anak, Berdasarkan Undang-Undang No. 23 Of 2002 Tentang Perlindungan Anak, Jakarta, UNICEF

[2] B. Ter Haar, 1985, Asas-Asas dan Susunan Hukum Adat, Translated K. ng Soebakti Poesponot, Jakarta Pradnya Paramita

[3] Ensiklopedi Indonesia, 1994, Jakarta, Ichtiar Baru Van Hoeve, cet. 1, Jilid 4

[4] Indonesia, the Law on Human Rights, No. 39 of 1999, LN, 1999 No. 165, Supplement No. 3886

[5] Indonesia, Act On Child Welfare, No. 4 of 1979, Gazette Of 1979 No. 32, Supplement No. 3143

[6] Isti Sulistyorini, 1997, Adopsi Menurut Staatsblad 1917 No. 129 Dan Kaitannya Dengan Pengangkatan Anak Menurut Hukum Adat, PENA, Jurnal IImu pengetahuan Dan Teknologi: V (9)

[7] Johnny Ibrahim, 2006, Teori dan Metodologi Penelitian Hukum Normatif, Malang, Bayumedia Publishing

[8] Koesparmono Irsan, 2009, Hukum dan Hak Asasi Manusia, Yayasan Brata Bhakti, Jakarta

[9] M. Budiarto, 1991, Pengangkatan Anak Ditinjau Dari Segi Hukum, Jakarta, Akademika Presindo

[10] Mukti Arto, 2006, Garis Batas Kekuasaan Pengadilan Agama dan Pengadilan Negeri, in Varia Peradilan year XXI No. 52, MA RI, Jakarta

[11] Government Regulation on the Implementation of Child Adoption, Government Regulation No. 54 of 2007, Gazette Of 2007 No. 123, Supplement No. 4768, Article 2

[12] Ronny Hanitijo Soemitro, 1988, Metodologi Penelitian Hukum dan Jurimetri, Jakarta, Ghalia Indonesia 